\title{
Note on sources
}

Although historians have for a long time known about the existence of lunacy investigation law, the sources relating to the law's use have remained elusive and underappreciated. ${ }^{1}$ Specifically, while there are many sources about the functioning of lunacy investigation law, the trial testimony, judges' statements, lawyers' interventions, appeals and witness statements have been difficult to locate for most jurisdictions in which this trial process took place. In order to write a history of lunacy investigation law in transatlantic perspective, this book has exploited two major sources: reports on lunacy trials that are found in the English Reports (see below), and a largely intact set of lunacy trial manuscripts found in the New Jersey State Archives.

The most comprehensive published interpretation of English lunacy trials for the early nineteenth-century period is Akihito Suzuki's Madness at Home: The Psychiatrist, the Patient, and the Family in England, 1820-1860. Suzuki's analysis is based on 196 commissions of lunacy that were published in The Times newspaper. Finding the original manuscript sources for these and earlier commissions of lunacy has so far proved next to impossible. ${ }^{2}$ However, case reports of many lunacy trials are now available online. The English Reports is a 179-volume compilation of case reports dating from 1220 to 1866 . As Peter Bartlett notes, 'the vast bulk of the cases date from the seventeenth to the mid-nineteenth centuries.' A convenient way to access English Reports relating to lunacy trials is through the search engine Justis, which, among other resources, provides an extensive online library of legal sources for the United Kingdom. ${ }^{4}$ Using the Justis search engine, I have collected case reports for over two hundred cases in lunacy, dating from Beverley's landmark case in 1598 to the beginning of the period covered by Akihito Suzuki's 
book in 1823. These reports vary in length and in the quality of their content, depending on their usefulness to the legal system at various subsequent periods in English history. But many of them are detailed, containing case summaries, the perspectives of the various participants and the observations and explanations of the Lord Chancellors. Although the majority of case reports on trials in lunacy pertain to the Court of Chancery, some describe trials played out in the Court of King's Bench and the ecclesiastical courts.

The paperwork that is largely absent from the case reports on lunacy trials in England is fully on display in the extant sources for New Jersey. Approximately 1,800 lunacy trials were found in boxes in the basement of the New Jersey State Courthouse, collected together at some point at the turn of the twentieth century into 'lunacy bundles'. Although intended for destruction, they have subsequently become part of the New Jersey State Archives' permanent manuscript collections. ${ }^{5}$ These hand-written sources, though uneven in length and quality, offer extensive witness testimonials from neighbours, friends and local authorities, lawyers' arguments, judges' deliberations, the machinations of the guardianship process and, occasionally, full retrials of earlier verdicts of non compos mentis. These sources allow for the reconstruction of the complex dynamics of the trial process and the equally complicated community and familial contexts within which the legal recourse to madness took place.

\section{Notes}

1 See the discussion in P. Bartlett, 'Legal madness in the nineteenth century', Social History of Medicine, 14:1 (2001), 107-31.

2 Suzuki notes that the original manuscripts for the period covered in his study 'were destroyed, unavailable, or scattered.' A. Suzuki, Madness at Home: The Psychiatrist, the Patient, and the Family in England, 1820-1860 (Berkeley: University of California Press, 2006), p. 26. He refers to a few records at The [British] National Archives, but the vast majority of the lunacy trials seem to have been lost. In 1998 I was informed by an archivist at The National Archives that, although the index to the commissions of lunacy was extant, the thousands of pieces of paper with the content of most trials was considered expendable during the First World War and had been recycled for the war effort. 
3 Bartlett, 'Legal madness', 113.

4 See http://www.justis.com/about/what-is-justis.aspx. Cases referenced in this volume are cited by volume number in English Reports (abbreviated as E.R.), followed by the case name and year(s) and page numbers. E.g. 88 E.R., Bennett and His Wife and Spencer and His Wife against Vade and Several Others, 1742, pp. 474-83.

5 A fuller discussion of these sources as they compare with asylum documents can be found in J. Moran 'A tale of two bureaucracies: asylum and lunacy law paperwork', Rethinking History, 22:3 (2018), 419-36. 